\title{
Allelopathic effects of two important exotic weeds, Ageratum houstonianum Mill. and Chromolaena odorata (L.) R.M. King \& H. Rob. on some crop plants
}

\author{
Noor Pertin ${ }^{1}$, J. Sutradhar ${ }^{2}$, A. P. Das ${ }^{1,3}$, \\ ${ }^{1}$ Department of Botany, Rajiv Gandhi University, Doimukh- 791112, Itanagar, Arunachal Pradesh, India \\ ${ }^{2}$ Department of Botany, Visva-Bharati, Santiniketan, 731235, West Bengal, India \\ E-mails: nukunu996@gmail.com; jsdhar1987@gmail.com; apdas.nbu@gmail.com \\ ${ }^{3}$ Communicating author \\ [Received 07.06.2018; Revised \& accepted 26.06.2018; Published 30.06.2018]
}

\begin{abstract}
Weeds are undesirable plants growing in an area where they are not wanted. These are generally highly competitive and adaptable to very wide environmental conditions. While competing with crop plants for light, nutrient and moisture contents of the soil, many weeds have allelopathic effects on crop plants. The present work investigated the allelopathic effects of two dominating exotic weeds Ageratum houstonianum Mill. and Chromolaena odorata (L.) R.M. King \& H. Rob. on (i) Sesame [Sesamum indicum L. of Pedaliaceae], (ii) Mustard [Brassica nigra (L.) K.Koch of Brassicaceae], (iii) Lai-patta/Mustard green [Brassica juncea (L.) Czern. of Brassicaceae], and (iv) Radish [Raphanus raphanistrum subsp. sativus (L.) Domin. of Brassicaceae], which showed the strong derogative effects on crop plants.
\end{abstract}

Key words: Ageratum houstonianum, Chromolaena odorata, Allelopathy, Local crops

\section{INTRODUCTION}

In agricultural science weed is generally defined as the unwanted plants which are growing in crop fields and competing with the crop plants with their short vegetative phase but with high reproductive capacity. The term Allelopathy was defined by Rice (1984) as direct or indirect inhibitory or beneficial effect by one organism on another through the production of chemical compounds (Cheng \& Cheng 2015). A large number of weed species shows allelopathic effects on different plants including crop plants in cultivated lands has been reported. Allelopathy is caused by the chemical compounds releasing into the surrounding environment by means of decomposition, volatilization and root exudation (Figure 1; Anonymous 1).

Several works related to Allelopathy has been worked out in different parts of the world, including India. Allelopathic effects of Cyperus rotundus L., Commelina benghalensis L., Parthenium hysterophorus L. and Prosopis juliflora (Sw.) DC., on sorghum, wheat, green gram, soybean, sunflower and groundnut was evaluated by Channappagoudar (2005). Allelopathic effect of Ageratum conyzoides (L.) L., was examined by Verma and Rao (2006) on seed germination, seedling growth, total protein content and protein profile of soybean. In their study they have also examined such effects of other weeds e.g. Cynodon dactylon (L.) Pers., Parthenium hysterophorus L., and Solanum nigrum L. [= Solanum americanum Mill.]. 


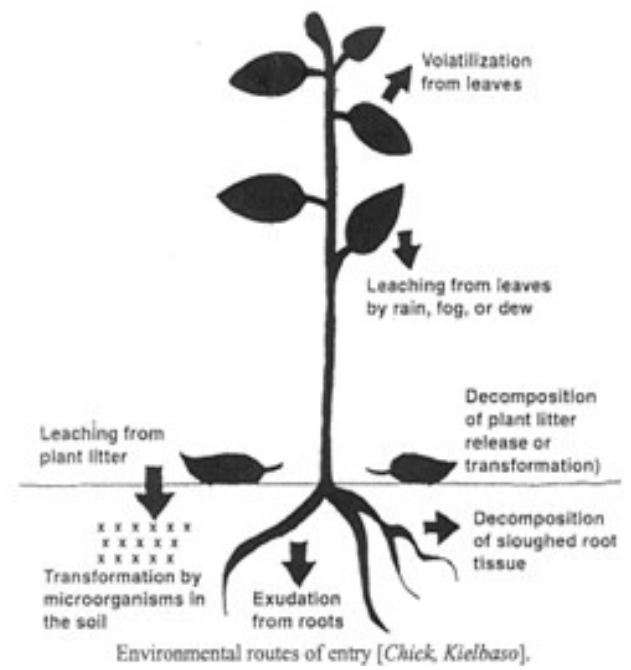

Figure 1. The possible ways of allelochemi$\mathrm{cal}$ release into the local environment

\section{Exotic weeds:}

The presence of exotic naturalizes plants in different floras is well known (Khuroo et al. 2012; Maiti \& Guha Bakshi 1981). Occurrence of such exotics in parts of the Eastern Himalaya has been earlier recorded by many workers including Das \& Chanda (1986) and Das (2002).

Two common exotic dominating species, Ageratum houstonianum Mill.is native to Central America and some parts of Mexico, but it becomes an invasive weed in different countries (Anonymous 2) including India; and Chromolaena odorata (L.) R.M. King \& H. Rob. is native to the Americas and has been introduced to tropical Asia and different parts of Africa and Australia (Anonymous 3) where they are widely naturalised. It is now important to see whether these two common

weeds has some effects on the local crop plants or not.

To test this hypothesis, four common crop plants of Arunachal Pradesh were selected: (i) Sesame [Sesamum indicum L. of Pedaliaceae], (ii) Mustard [Brassica nigra (L.) K.Koch of Brassicaceae], (iii) Lai-patta/Mustard green [Brassica juncea (L.) Czern. of Brassicaceae], and (iv) Radish [Raphanus raphanistrum subsp. sativus (L.) Domin of Brassicaceae]. Objective of the present study was manifold, (a) to understand the interaction between crops \& weeds, (b) evaluation of the effects of weeds on the test crop plants in terms of germination rate and average length of root and stem at the initial growth stage, (c) development of the data sources which reflect quantitative measure of the growth and the management of that particular weed population.

\section{MATERIALS AND METHODS}

For the experimental procedures Putman \& Duke (1978), Datta \& Ghosh (1987), Acharya (1998), Kadir (2001), and Ghosh (2006) were followed.

\section{Preparation of extract and leachate solutions:}

Mature and healthy crop plant seeds of locally cultivated varieties were collected from the farmers and stored at $4^{\circ} \mathrm{C}$ in brown paper envelopes. Freshly collected aerial plant part of weeds were used to make aqueous extract (100 g in $250 \mathrm{ml}$ of distilled water). Similarly, for leachate solution, $100 \mathrm{~g}$ of fresh plant material was soaked in distilled water for 72 hours. In both the cases filtrate $(1: 2.5 \mathrm{w} / \mathrm{v})$ was treated as stock solution (strained through filter paper) and by subsequent dilution of the stock with distilled water different concentration gradients $(1: 5,1: 10,1: 20 \mathrm{w} / \mathrm{v})$ were prepared. There was a control set using distilled water in each set of experiment. Two replicas were maintained for each set to nullify the experimental error.

Germination test: The tests using A. houstonianum were conducted in the month of March 2018 and the other tests with C. odorata was done in November 2017. Healthy and mature crop seeds (Sesame, Mustard, Lai-patta \& Radish) were allowed to germinate in control (distilled water) and in different concentration of test solutions (1:2.5, 1:5, 1:10 and $1: 20 \mathrm{w} / \mathrm{v})$ of Ageratum houstonianum and Chromolaena odorata separately for extract 
and leachate. The experiments were conducted at room temperature under normal light during the day and dark at night. The germinated seeds were counted regularly and the linear length of roots, stem and total seedling length were recorded.

Germination Percentage: The germination percentage was calculated with the formula

$$
\text { Germination Percentage }=\frac{\text { Total number of germinated seeds }}{\text { Total number of seeds sown }} \times 100
$$

\section{RESULTS AND DISCUSSIONS}

For the present set of experiments extract and leachate solutions of two weeds were used for four different crop plants (Sesame, Mustard, Lai-patta \& Radish) were used separately. For each set, total germinated seeds were counted and linear length of root, stem and the whole seedling were also measured.

Germination \%: The germination percentage decreases along with the increasing concentration of extract and leachate solutions of $\boldsymbol{A}$. houstonianum and $\boldsymbol{C}$. odorata in compared to control set. The effects of both the weeds are almost same in all the crop seed germination. In case of $\boldsymbol{A}$. houstonianum the highest rate of germination (93\%) was found in mustard, in the lowest con. i.e. 1:20 w/v extract solution; followed by radish $(86 \%)$ in 1:20 $\mathrm{w} / \mathrm{v}$ leachate soln. The lowest germination rate (26\%) showed by Lai-patta (mustard green) in 1:2.5 w/v extract soln. which was followed by $30 \%(1: 2.5 \mathrm{w} / \mathrm{v}$ leachate soln.) in mustard and $33 \%(1: 2.5 \mathrm{w} / \mathrm{v}$ extract soln.) in sesame (Table 1). That means A. houstonanum has

Table 1. Effects of Ageratum houstonianum extract and leachate at different concentrations on germination and seedling growth of test crop plants.

\begin{tabular}{|c|c|c|c|c|c|c|c|c|c|}
\hline \multirow[t]{2}{*}{ Parameters } & \multirow{2}{*}{$\begin{array}{l}\text { Con. } \\
(w / v)\end{array}$} & \multicolumn{2}{|c|}{ Sesame } & \multicolumn{2}{|c|}{ Mustard } & \multicolumn{2}{|c|}{ Lai-patta } & \multicolumn{2}{|c|}{ Radish } \\
\hline & & Extr. & $\begin{array}{c}\text { Leac } \\
\text { h. }\end{array}$ & Extr. & $\begin{array}{c}\text { Leac } \\
\text { h. }\end{array}$ & Extr. & $\begin{array}{c}\text { Leac } \\
\text { h. }\end{array}$ & Extr. & Leach. \\
\hline \multirow{5}{*}{$\begin{array}{c}\text { Germination } \\
\%\end{array}$} & Control & 70 & 86 & 96 & 100 & 66.6 & 90 & 90 & 93 \\
\hline & $1: 2.5$ & 33 & 46 & 40 & 30 & 26 & 43 & 36 & 40 \\
\hline & $1: 5$ & 50 & 66.6 & 50 & 36 & 40 & 50 & 53 & 80 \\
\hline & $1: 10$ & 63 & 73.3 & 80 & 80 & 53 & 63 & 80 & 83 \\
\hline & $1: 20$ & 66 & 83.3 & 93 & 86.6 & 60 & 76.6 & 83 & 86 \\
\hline \multirow{5}{*}{$\begin{array}{l}\text { Mean root } \\
\text { length }(\mathrm{cm}) \\
\text { per seedling }\end{array}$} & Control & 17.5 & 10.5 & 43.4 & 47.5 & 28.6 & 37.4 & 38.4 & 26.2 \\
\hline & $1: 2.5$ & 5.3 & 2.8 & 13.3 & 8.4 & 15.7 & 8.5 & 14.1 & 4.1 \\
\hline & $1: 5$ & 16.3 & 13.4 & 26.8 & 12.7 & 38.6 & 12.3 & 38.1 & 18.1 \\
\hline & $1: 10$ & 22.1 & 19.3 & 37.8 & 30.7 & 33.1 & 23.2 & 49.6 & 45.3 \\
\hline & $1: 20$ & 25.2 & 22.8 & 49.2 & 49.3 & 34 & 24.9 & 45.3 & 42.4 \\
\hline \multirow{5}{*}{$\begin{array}{l}\text { Mean stem } \\
\text { length }(\mathrm{cm}) \\
\text { per seedling }\end{array}$} & Control & 10.4 & 4.3 & 21.1 & 20.7 & 17.6 & 11.5 & 24.4 & 18.9 \\
\hline & $1: 2.5$ & 8.4 & 6.5 & 18.7 & 15.4 & 21.3 & 15.7 & 19.8 & 10.2 \\
\hline & $1: 5$ & 12.1 & 12.8 & 23.3 & 16 & 24.6 & 14 & 22.9 & 17.6 \\
\hline & $1: 10$ & 13.3 & 13.2 & 22.6 & 16.8 & 21.6 & 14.8 & 27.9 & 24.9 \\
\hline & $1: 20$ & 10.1 & 9.5 & 27.3 & 17.7 & 22.2 & 15 & 24.3 & 24.9 \\
\hline \multirow{5}{*}{$\begin{array}{c}\text { Average } \\
\text { length }(\mathrm{cm}) \text { of } \\
\text { seedling }\end{array}$} & Control & 27.9 & 14.8 & 64.5 & 68.2 & 46.2 & 48.9 & 62.8 & 45.5 \\
\hline & $1: 2.5$ & 13.7 & 9.3 & 32 & 23.8 & 37 & 24.2 & 33.9 & 14.3 \\
\hline & $1: 5$ & 28.4 & 26.2 & 50.1 & 28.7 & 63.2 & 26.2 & 61 & 35.7 \\
\hline & 1:10 & 35.4 & 32.5 & 60.4 & 47.5 & 54.7 & 38 & 77.5 & 70.2 \\
\hline & $1: 20$ & 35.3 & 32.3 & 76.5 & 67 & 56.2 & 39.9 & 69.6 & 67.3 \\
\hline
\end{tabular}


Table 2. Effects of Chromolaena odorata extract and leachate at different concentrations on germination and seedling growth of test crop plants.

\begin{tabular}{|c|c|c|c|c|c|c|c|c|c|}
\hline \multirow[t]{2}{*}{ Parameters } & \multirow{2}{*}{$\begin{array}{l}\text { Con. } \\
(w / v)\end{array}$} & \multicolumn{2}{|c|}{ Sesame } & \multicolumn{2}{|c|}{ Mustard } & \multicolumn{2}{|c|}{ Lai-patta } & \multicolumn{2}{|c|}{ Radish } \\
\hline & & Extr. & Leach. & Extr. & Leach. & Extr. & Leach. & Extr. & Leach. \\
\hline \multirow[t]{5}{*}{ Germination \% } & Control & 100 & 96 & 93 & 100 & 93 & 93 & 96 & 96 \\
\hline & $1: 2.5$ & 50 & 53 & 66 & 33 & 50 & 66 & 80 & 50 \\
\hline & $1: 5$ & 73 & 66 & 86 & 56 & 66 & 73 & 83 & 83 \\
\hline & $1: 10$ & 80 & 76 & 90 & 66 & 83 & 80 & 83 & 90 \\
\hline & $1: 20$ & 93 & 86 & 93 & 90 & 86 & 86 & 90 & 93 \\
\hline \multirow{5}{*}{$\begin{array}{l}\text { Mean root } \\
\text { length }(\mathrm{cm}) \text { per } \\
\text { seedling }\end{array}$} & Control & 34.8 & 43.9 & 24.5 & 63.7 & 37.1 & 38.6 & 29 & 55.3 \\
\hline & $1: 2.5$ & 5.3 & 10.6 & 6.2 & 2.6 & 4 & 4.8 & 22.2 & 1.7 \\
\hline & $1: 5$ & 14.2 & 22.6 & 24.2 & 33.3 & 32.8 & 27.3 & 22.8 & 19.8 \\
\hline & $1: 10$ & 31.7 & 25 & 26.4 & 45.4 & 26.4 & 37.8 & 26.3 & 27.1 \\
\hline & $1: 20$ & 27.9 & 31.7 & 25.2 & 58.2 & 29.6 & 46.8 & 29.2 & 21.5 \\
\hline \multirow{5}{*}{$\begin{array}{l}\text { Mean stem } \\
\text { length }(\mathrm{cm}) \text { per } \\
\text { seedling }\end{array}$} & Control & 16.6 & 14.4 & 15.1 & 17.2 & 16.5 & 17.4 & 21.3 & 21 \\
\hline & $1: 2.5$ & 10.2 & 13.8 & 13.2 & 10.7 & 11.1 & 15.8 & 16.1 & 4.8 \\
\hline & $1: 5$ & 17.6 & 10.9 & 18.7 & 23.4 & 24 & 19.6 & 6.6 & 10.5 \\
\hline & $1: 10$ & 20.2 & 14.6 & 21.5 & 26 & 24.4 & 29.8 & 14.9 & 19.4 \\
\hline & $1: 20$ & 18.4 & 14.2 & 20.1 & 26.6 & 22.3 & 30.7 & 19.3 & 12.3 \\
\hline \multirow{5}{*}{$\begin{array}{l}\text { Average } \\
\text { length }(\mathrm{cm}) \text { of } \\
\text { seedling }\end{array}$} & Control & 51.4 & 58.3 & 39.6 & 80.9 & 53.6 & 55.7 & 50.3 & 76.3 \\
\hline & $1: 2.5$ & 15.5 & 24.4 & 19.4 & 13.3 & 15.1 & 20.6 & 38.3 & 6.5 \\
\hline & $1: 5$ & 31.8 & 33.5 & 42.7 & 56.7 & 56.8 & 46.9 & 29.4 & 30.3 \\
\hline & $1: 10$ & 51.9 & 39.6 & 47.9 & 71.4 & 50.8 & 67.6 & 41.2 & 46.5 \\
\hline & $1: 20$ & 46.3 & 45.9 & 45.3 & 84.8 & 51.9 & 77.5 & 48.5 & 33.8 \\
\hline
\end{tabular}
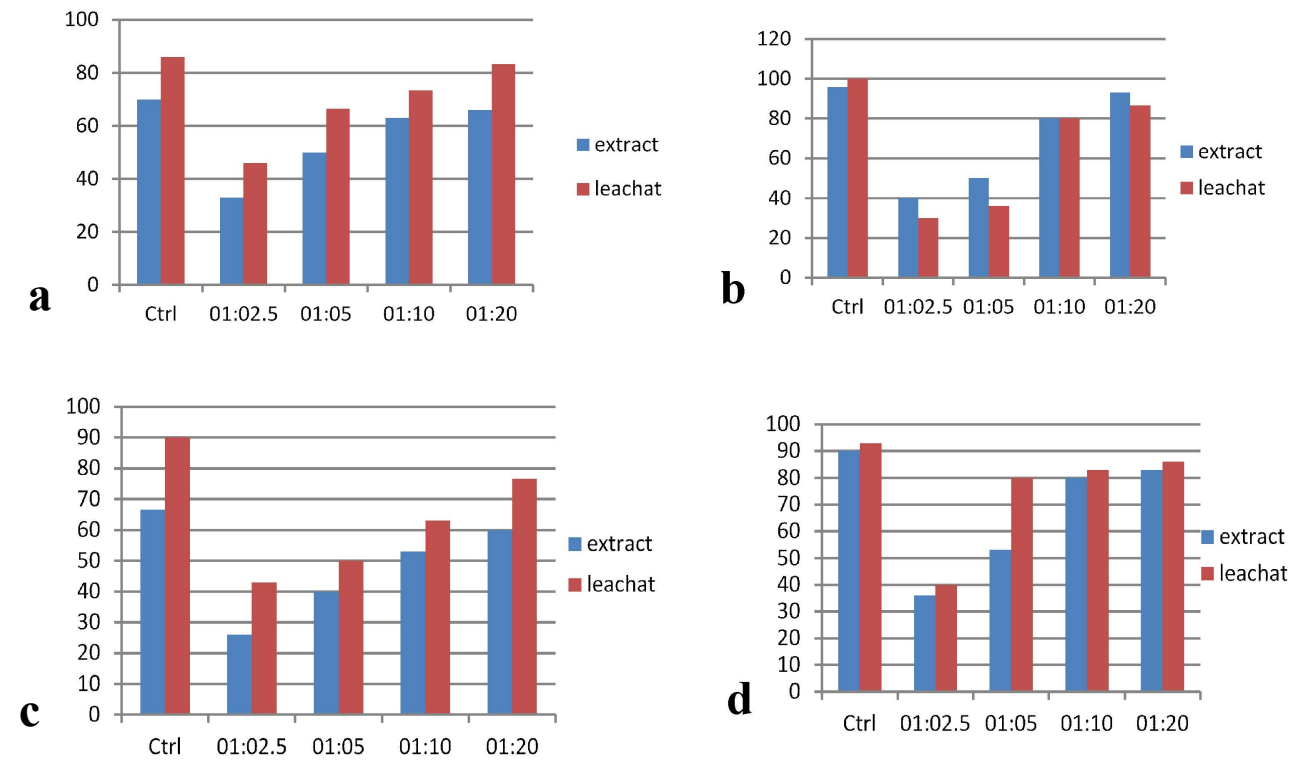

Figure 1. Effect of Ageratum houstonianum extract and leachate on Germination \% of (a) Sesame (b) Mustard (c) Lai-patta \& (d) Radish.

strong inhibitory effect on germination of Lai-patta, mustard and sesame than radish. Whereas in $C$. odorata lowest value for germination rate $(33 \%)$ was found to occur in mustard, in $1: 2.5 \mathrm{w} / \mathrm{v}$ leachate soln. Followed by $50 \%$ (in mustard $1: 2.5 \mathrm{w} / \mathrm{v}$ extract $\& 1: 2.5 \mathrm{w} / \mathrm{v}$ leachate 
solution) (Table 2). From the results we can conclude that $C$. odorata more adversely affect the germination of Mustard seeds than the other crop plants.
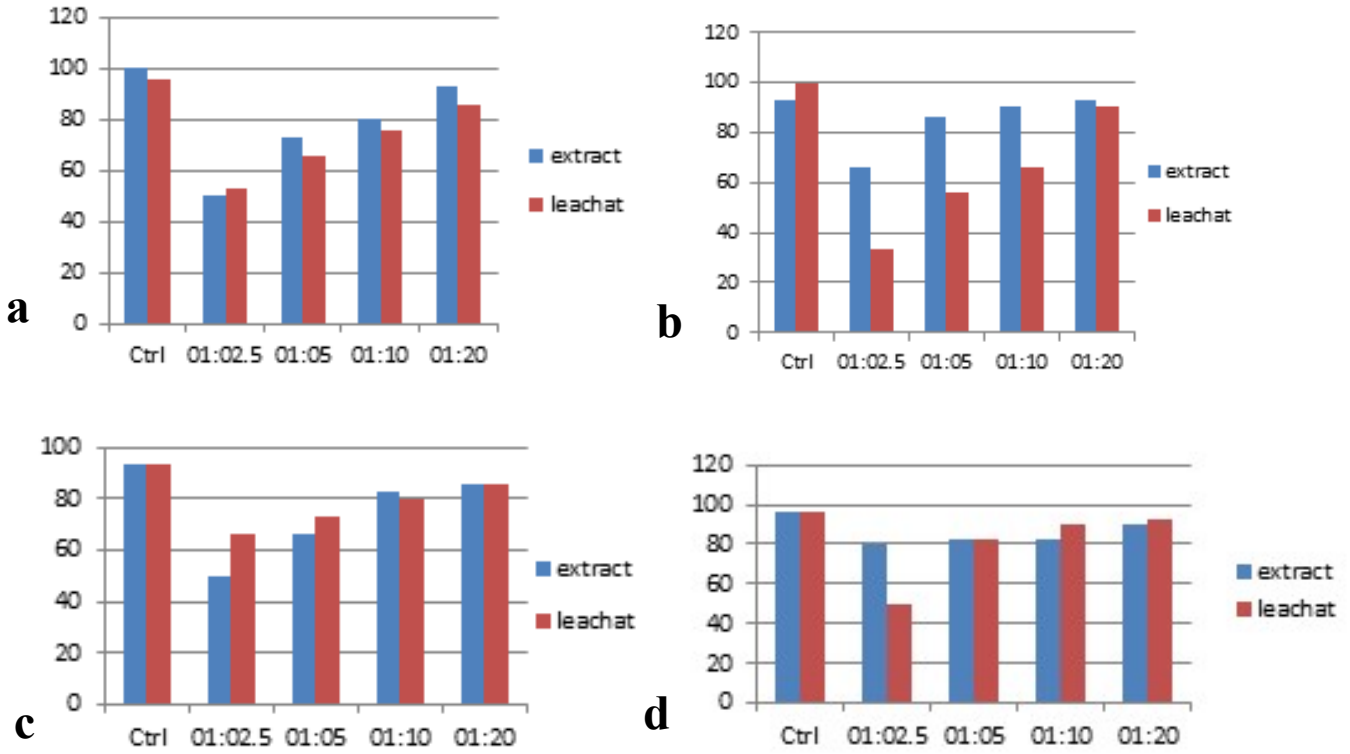

Figure 3. Effect of Chromolaena odorata extract and leachate on Germination \% of (a) Sesame, (b) Mustard, (c) Lai-patta, and (d) Radish.

Table 3. Mean root length of crop seedlings in presence of highly concentrated extract and leachate solution(1:2.5 w/v) of (A) Ageratum haustonianum, and (B) Chromolaena odorata

\begin{tabular}{|c|c|c|c|c|c|c|c|c|}
\hline \multicolumn{1}{|c|}{ A Ageratum haustonianum } \\
\hline \multicolumn{1}{|c|}{ Mean root length (cm) in 1:2.5 w/v con. and Control set } \\
\hline & Sesame & \multicolumn{2}{|c|}{ Mustard } & \multicolumn{2}{|c|}{ Lai patta } & \multicolumn{2}{c|}{ Radish } \\
\hline \multirow{3}{*}{ Extract } & $\mathbf{1 : 2 . 5}$ & Ctrl. & $\mathbf{1 : 2 . 5}$ & Ctrl. & $\mathbf{1 : 2 . 5}$ & Ctrl & $\mathbf{1 : 2 . 5}$ & Ctrl \\
\cline { 2 - 9 } & 5.3 & 17.5 & 13.3 & 43.4 & 15.7 & 28.6 & 14.1 & 38.4 \\
\hline Leachate & 2.8 & 10.5 & 8.4 & 47.5 & 8.5 & 37.4 & 4.1 & 26.2 \\
\hline
\end{tabular}

\begin{tabular}{|c|c|c|c|c|c|c|c|c|}
\hline \multicolumn{1}{|c|}{ B Chromolaena odorata } \\
\hline \multicolumn{1}{|c|}{ Mean root length (cm) in 1:2.5 w/v con. and Control set } \\
\hline \multirow{3}{*}{ Extract } & Sesame & \multicolumn{2}{c|}{ Mustard } & \multicolumn{2}{c|}{ Lai patta } & \multicolumn{2}{c|}{ Radish } \\
\cline { 2 - 9 } & $\mathbf{1 : 2 . 5}$ & Ctrl. & $\mathbf{1 : 2 . 5}$ & Ctrl. & $\mathbf{1 : 2 . 5}$ & Ctrl & $\mathbf{1 : 2 . 5}$ & Ctrl \\
\hline Leachate & 10.6 & 34.8 & 6.2 & 24.5 & 4 & 37.1 & 22.2 & 29 \\
\hline
\end{tabular}

Mean Root length (cm): Subsequent dilution of stock solution $(1: 2.5 \mathrm{w} / \mathrm{v})$ into 1:5, 1:10 and $1: 20 \mathrm{w} / \mathrm{v}$ affected the initial growth of seedlings; upto $1: 10 \mathrm{w} / \mathrm{v}$ solution increasing concentration of weed solution decreases the root length. But, almost in all the cases highest dilution of the stock solution $(1: 20 \mathrm{w} / \mathrm{v})$ showed stimulatory effects on the root and stem growth, it may lead to the adverse effects little later. But till that period of growth it was not clear. By using the $A$. houstonianum the lowest mean root length $(2.8 \mathrm{~cm})$ was of sesame in $1: 2.5 \mathrm{w} / \mathrm{v}$ leachate soln, it was then followed by $4.1 \mathrm{~cm}(1: 2.5 \mathrm{w} / \mathrm{v}$ leachate solution $)$ in radish and $5.3 \mathrm{~cm}(1: 2.5 \mathrm{w} / \mathrm{v}$ extract solution) in sesame [Table 3 (A)]. The results revealed that A. houstonianum have severe inhibitory effects on root growth of sesame than mustard, lai-patta and radish. Whereas in $C$. odorata minimum root growth $(1.7 \mathrm{~cm})$ was found in radish, maintained in 1:2.5 w/v leachate solution followed by $4 \mathrm{~cm}$ and $4.8 \mathrm{~cm}$ in lai-patta in $1: 2.5 \mathrm{w} / \mathrm{v}$ extract and leachate solutions respectively [Table 3 (B)].

Mean stem length (cm): A. houstonianum inhibit the stem growth in it's highest concentrated test solution $(1: 2.5 \mathrm{w} / \mathrm{v}$ extract solution) in case of sesame, mustard, and radish. 
50 Allelopathic effects of two exotic weeds on local crops

Table 4: Mean stem length of crop seedlings in highly concentrated extract and leachate solution of (A) Ageratum haustonianum and (B) Chromolaena odorata, with respect to control (Ctrl.).

\begin{tabular}{|c|c|c|c|c|c|c|c|c|}
\hline \multicolumn{7}{|c|}{ A Ageratum haustonianum } \\
\hline \multicolumn{1}{|c|}{ Mean stem length (cm) in 1:2.5 w/v con. and Control set } \\
\hline \multirow{3}{*}{ Extract } & Sesame & \multicolumn{2}{|c|}{ Mustard } & \multicolumn{2}{|c|}{ Lai patta } & \multicolumn{2}{c|}{ Radish } \\
\cline { 2 - 10 } & $\mathbf{1 : 2 . 5}$ & Ctrl. & $\mathbf{1 : 2 . 5}$ & Ctrl. & $\mathbf{1 : 2 . 5}$ & Ctrl & $\mathbf{1 : 2 . 5}$ & Ctrl \\
\cline { 2 - 9 } & 8.4 & 10.4 & 18.7 & 21.1 & 21.3 & 17.6 & 19.8 & 24.4 \\
\hline Leachate & 6.5 & 4.3 & 15.4 & 20.7 & 15.7 & 11.5 & 10.2 & 18.9 \\
\hline
\end{tabular}

\begin{tabular}{|c|c|c|c|c|c|c|c|c|}
\hline \multicolumn{1}{|c|}{ B Chromolaena odorata } \\
\hline \multicolumn{1}{|c|}{ Mean stem length $(\mathrm{cm})$ in 1:2.5 w/v con. and Control set } \\
\hline & Sesame & \multicolumn{2}{|c|}{ Mustard } & \multicolumn{2}{|c|}{ Lai patta } & \multicolumn{2}{c|}{ Radish } \\
\hline \multirow{3}{*}{ Extract } & $\mathbf{1 : 2 . 5}$ & Ctrl. & $\mathbf{1 : 2 . 5}$ & Ctrl. & $\mathbf{1 : 2 . 5}$ & Ctrl. & $\mathbf{1 : 2 . 5}$ & Ctrl. \\
\cline { 2 - 9 } & 10.2 & 16.6 & 13.2 & 15.1 & 11.1 & 16.5 & 16.1 & 21.3 \\
\hline Leachate & 13.8 & 14.4 & 10.7 & 17.2 & 15.8 & 17.4 & 4.8 & 21 \\
\hline
\end{tabular}

Lai-patta didn't show any significant effects in comparing with the control set [Table 4(A)]. It has been observed that, along with the increasing concentration of $C$. odorata in test solution, the linear length of stem decreases up to $1: 10 \mathrm{w} / \mathrm{v}$ concentration, in highest diluted condition i.e. in 1:20 w/v, showed increased stem growth than the control set in all the crop seedlings [Table $4(\mathrm{~B})]$.

\section{Conclusion}

In nature, every land, whether it is cultivated or not, contains specific amount of resources for the growth and development of natural vegetation. The density of this growth promoting resources varies according to the soil type and other environmental conditions. When the weed plant grows along with the crops in fields, they utilise a large amount of these resources that may lead to the reduction of quantity and quality of the agricultural products (Anonymous 2013).

The knowledge obtained from the above experiment can be applied to recognize those weedy plants having negative impacts on crops and can be removed from field in their early stage of growth. Allelopathic studies, therefore offers possibilities for a better agricultural practices.

In our country weed accounts for $37 \%$ annual loss of agricultural produce. The weedy plants are significant pests of crops those may cause maximum loss of agronomic products (Das 2008).

In the world, around 30,000 weed species are recognized, out of these 18,000 species cause damage to crops. It has been estimated that occurrence of weed in crop fields cause $5 \%$ loss to production even in most developed countries, $10 \%$ loss in less developed countries and $25 \%$ loss in the least developed countries (Leela Rani \& Raju 2011).

So, the presently acquired knowledge on the allelopathic effects of two exotic weeds will be of much use in minimizing the loss of crop production in the areas affected by these species.

\section{LITERATURE CITED}

Acharya, A. 1998. Studies on the distribution, phenology, and reproductive potential of some crop field weeds of Malda District, West Bengal, India. Ph.D. Thesis, University of North Bengal.

Anonymous 1: https://edis.ifas.ufl.edu/hs186

Anonymous 2: https://en.wikipedia.org/wiki/Ageratum_houstonianum

Anonymous 3: https://en.wikipedia.org/wiki/Chromolaena_odorata 
Anonymous 2013. Effects of weeds on wheat, www1. agric. gov. ab. ca/\$department/dept docs. Nsf / all/ crop1280; Feb 4, 2013. (Agronomy Guide-Penn State extension. extension. psu. edu/agronomy-guide/pm/sec1/sec12a).

Khuroo, A.A.; Reshi, Z.A.; Malik, A.H.; Weber, E.; Rashid, I. \& Dar, G.H. 2012. Alien flora of India: taxonomic composition, invasion status and biogeographic affiliations. Biol Invasions 14: 99 - 113. DOI 10.1007/s10530-011-9981-2

Channappagoudar, B.B. 2005. Allelopathic Effect of Aqueous Extracts of Weed Species on Germination and Seedling Growth of Some Crops. Journal of Agricultural Science 18(4): $916-920$.

Cheng, F. \& Cheng, Z. 2015. Research Progress on the use of Plant Allelopathy in Agriculture and the Physiological and Ecological Mechanisms of Allelopathy. Frontiers of Plant Science 6: 1020.

Das, A.P. 2002: Survey of naturalised exotics in the flora of Darjiling Hills, West Bengal, (India). J. Econ. Tax. Bot. 26(1): $31-37$.

Das, A.P. \& Chanda, S. 1986. Notes on some naturalised exotics in Darjeeling Hills, West Bengal (India). Indian Bot. Rep. 5(2): 144 - 147.

Das, T.K. 2008 Weed Management: Weeds and their Control Methods. Book chapter. Division of Agronomy, Indian Agricultural Research Institute, New Delhi - 110012.

Dutta, S.C. \& Ghosh, K.N. 1987. Allelopathy in two species of Chenopodium - inhibition of germination and seedling growth in certain weeds. Acta Societies Botanicorum Poloniae. 56(2): $257-270$.

Ghosh, C. 2006. Biology of Tea Garden Weeds in Darjeeling District of West Bengal (India). Ph.D. Thesis, North Bengal University.

Kadir, A.K.M. Manzur. 2001. Ecology of Subhimalayan Herblands in Darjeeling with special emphasis on Streptocaulon sylvestre Wight - an Endangered and Endemic Plant. Ph.D. Thesis, North Bengal University.

Leela Rani, P. \& Raju, M.S. 2011. Lecture notes on weed management agro-202. Department of Agronomy College of Agriculture, Acharya N.G Ranga Agricultural University, Rajendranagar, Hyderabad. A Text Book - acharya ng ranga agricultural university.

Maiti, G.G. \& Guha Bakshi, D.N. 1981. Invasion of exotic weeds in West Bengal since 1903: Dicotyledons and Monocotyledons. J. Econ. Tax. Bot. 2: $156-168$.

Putman, A.R. \& Duke, W.B. 1978. Allelopathy in agroecosystems. Ann. Rev. Phytopath. $16: 431-451$.

Rice, E.L. 1984. Allelopathy, $2^{\text {nd }}$ edn. Academic Press, New York.

Verma, M. \& Rao, P.B. 2006. Allelopathic effect of four weed species extracts on germination, growth and protein in different varieties of Glycine max (L.) Merrill. J. Environ. Biol. 27(3): $571-577$. 